\title{
Indice de materias.
}

Prólogo . . . . . . . . . . . . . . . 5

Pauta . . . . . . . . . . . . . . . . 11

Tabla de los telegramas cambiados . . . . . . . . . . . . 12

Documentos . . . . . . . . . . . . . . . . . . 14

Apéndice: Indicación del contenido de los telegramas de París cuyo texto no se publica . . . . . . . . . . . . . . . . . 49 
